Revista de Psicología Vol. 37 (1), 2019 (ISSN 0254-9247)

\title{
Scale of Coping with Pain for Dancers (COPAIN-Dancer): Construction and validity evidences
}

\author{
Andressa Melina Becker da Silva ${ }^{1}$, Sônia Regina Fiorim Enumo ${ }^{2}$, Lucas \\ de Francisco Carvalho ${ }^{3}$, Wagner de Lara Machado ${ }^{4}$, Isabella Goulart \\ Bittencourt ${ }^{5}$, Murilo Fernandes de Araújo ${ }^{6}$, Renan de Morais Afonso ${ }^{7}$, Jodi \\ Dee Hunt Ferreira do Amaral ${ }^{8}$, Tatiane Stephan Rocchetti Luz ${ }^{9}$ \\ Universidade de Sorocaba, Brasil', Pontifícia Universidade Católica de \\ Campinas, Brasil 2,4,6,8,9, Universidade São Francisco, Brasil', Center for \\ Psychosocial Attention Microregional of Timbón, Brasil, Universidade \\ Estadual de Campinas, Brasil
}

Dancers experience daily pain that impacts their health, but the pain is mediated by coping with pain. We elaborated the Scale of Coping with Pain for Dancers (COPAIN-Dancer) based on the Motivational Theory of Coping with 12 categories of coping. This study presents the validity of the COPAIN-Dancer. The content analysis conducted judges reduced 118 items to 35, that were then administered to 386 Brazilian dancers between 10 and 19 years old $(M=15.35$; $S D=3.36$ ). Applying the Exploratory Factor Analysis, a low correlation resulted among the items that represent the 12 coping categories. However, after conducting Item Response Theory and Network Analysis, we obtained two factors: Adaptive Coping and Maladaptive Coping. The COPAIN-DANCER shows reliability and can be used in adolescent dancers. Keywords: coping, pain, dancers, test validity, test construction.

1 Ph.D. in Psychology, Professor of Psychology at Universidade de Sorocaba, Brazil. Address: Av. das Pitangueiras, 163, Cond. Margaridas, Bloco E, ap. 128, Vossoroca, Votorantim, SP, Brazil. Zip Code: 18119-372. Contact: andressa_becker@hotmail.com. ORCID: https:// orcid.org/0000-0001-5630-7843

2 Ph.D. in Psychology, Emeritus Professor of Universidade Federal do Espírito Santo; Professor of Graduate Program of Psychology, and Graduate of Program in Health Sciences at Pontifícia Universidade Católica de Campinas (PUC-Campinas), Campinas, São Paulo State, Brazil. Address: Av. John Boyd Dunlop, s/n - Jardim Ipaussurama, Campinas, SP, Zip Code: 13060-904. Contact: sonia.enumo@puc-campinas.edu.br. ORCID: http://orcid. org/0000-0001-9038-6151

3 Ph.D. in Psychology, Professor of Graduate Program of Psychology at Universidade São Francisco, Itatiba, Brazil. Address: Alexandre Rodrigues Barbosa Street, 45, Centro, Itatiba-SP, Brazil. Zip Code: 13251-900. Contact: lucas@labape.com.br. ORCID: https:// orcid.org/0000-0002-3274-9724 


\section{Escala de afrontamiento del dolor para bailarines (COPAIN-Dancer): Construcción y evidencias de validez}

Los bailarines viven diariamente con dolores que afectan su salud, pero que son mediados por el proceso de afrontamiento. Este estudio presenta la Escala de afrontamiento del dolor para bailarines (COPAIN-Dancer), basado en la Motivational Theory of Coping, y sus evidencias de validez. Jueces evaluaron 118 ítems a su validez de contenido. Los ítems se redujeron a 35 y se administraron a 386 bailarines entre 10-19 ańos $(M=15.35 ; D E=3.36)$. Aplicando análisis factorial exploratorio (EPT), se dio una baja correlación entre los ítems que representan a las 12 familias de afrontamiento teorizadas. Sin embargo, utilizando la Teoría de Respuesta al Ítem y Análisis de Redes, se obtuvo dos factores: Afrontamiento Adaptativo y Afrontamiento Maladaptivo. El COPAIN-Dancer muestra fiabilidad, y puede ser utilizado en bailarines adolescentes.

Palabras clave: afrontamiento, dolor, bailarines, validación de test, construcción de test.

\section{Escala de Coping da Dor para Bailarinos (COPAIN-Dancer): Construçáo e evidências de validade}

Os bailarinos convivem diariamente com dores que afetam sua saúde, mas mediados pelo processo de coping. Este estudo apresenta a Escala de Coping da Dor para Bailarinos (COPAIN-Dancer), baseada na Motivational Theory of Coping, e suas evidências de validade. Os juízes avaliaram 118 itens quanto à validade de conteúdo. Os itens foram reduzidos para 35 e aplicados a 386 bailarinos entre 10 e 19 anos $(M=15.35 ; S D=3.36)$. Aplicando a análise fatorial exploratória (AFE), foi encontrada uma baixa correlação entre os elementos que representam 12 famílias de coping teoricamente embasadas. Entretanto, pela Teoria da

$4 \quad$ Ph.D. in Psychology; Professor of Graduate Program of Psychology at PUC-Campinas, Brazil. Address: Av. John Boyd Dunlop, s/n - Jardim Ipaussurama, Campinas, SP, Zip Code: 13060 904. contact: wag_psico@yahoo.com.br. ORCID: http://orcid.org/0000-0001-5555-5116 Psychologist of Center for Psychosocial Attention Microregional of Timbó, Timbó, Brazil. Address: Marechal Floriano Peixoto Street, 941, Bl. D, Ap. 204, Padre Martinho Stein, Timbó, SC, Brazil. Zip Code: 88065-000. Contact: isabellagoulartb@gmail.com. ORCID: https://orcid.org/0000-0001-8367-9298

6 Master student of Graduate Program of Psychology at PUC-Campinas, Brazil. Address: Av. John Boyd Dunlop, s/n - Jardim Ipaussurama, Campinas - SP, Zip Code: 13060-904. contact: mfaraujo94@gmail.com. ORCID: https://orcid.org/0000-0003-1707-4973

7 Psychologist of Department of Medical Psychology and Psychiatry, Faculty of Medical Sciences, Universidade Estadual de (UNICAMP), Brazil. Address: Av. Engenheiro Antonio Francisco de Paula Souza, 3007, bloco 12, ap. 21, Jardim São Gabriel, Campinas-SP, Brazil. Zip Code: 13045-903. Contact: renan_afonso18@hotmail.com. ORCID: https://orcid. org/0000-0003-2729-4339

8 Doctorate student at Graduate Program of Psychology at PUC-Campinas, Brazil. Address: Av. John Boyd Dunlop, s/n, Jardim Ipaussurama, Campinas, SP, Brazil. CEP: 13060-904. Contact: jdhfda@yahoo.com.br. ORCID: https://orcid.org/0000-0003-1707-4973

9 Master student at Graduate Program of Psychology at PUC-Campinas, Brazil. Address: Av. John Boyd Dunlop, s/n - Jardim Ipaussurama, Campinas, SP, Zip Code: 13060-904. Contact: tatty_luz@hotmail.com. ORCID: https://orcid.org/0000-0002-2219-2336 
Resposta ao Item e Análise de Rede, foram obtidos dois fatores: Coping Adaptativo e Coping Mal Adaptativo. O COPAIN-Dancer mostra confiabilidade e pode ser indicado para dançarinos adolescentes.

Palavras-chave: coping, dor, bailarinos, validade do teste, construção do teste.

\section{Échelle d'Adaptation à la Douleur pour les Danseurs (COPAIN-Dancer): Preuves de construction et de validité}

Les danseurs vivent chaque jour dans une douleur qui a un impact sur leur santé, mais ils sont médiés par le processus d'adaptation. Pour accéder à ce processus, nous avons élaboré l'Échelle d'Adaptation à la Douleur pour les Danseurs (COPAIN-DANCER), basée sur la Motivational Theory of Coping, avec 12 familles de coping. Cette étude présente le COPAINDancer et ses preuves de validité. L'analyse de contenu par les juges a réduit 118 items à 35, qui ont été administrés à 386 danseurs brésiliens avec 10-19 ans $(M=15.35 ; S D=3.36)$. En appliquant l'analyse factorielle exploratoire, une faible corrélation est apparue parmi les items qui représentent les 12 familles. Cependant, grâce à la Théorie de la Réponse à l'item et à l'analyse du réseau, nous avons obtenu deux facteurs: Adaptative et Maladaptive Coping. La COPAIN-Dancer fait preuve de fiabilité et peut être indiqué aux danseurs adolescents. Mots-clés: adaptation, douleur, des danseurs, validité du test, construction du test. 
The International Association for the Study of Pain (IASP, 2016, on line) defines pain as "An unpleasant sensory and emotional experience associated with actual or potential tissue damage, or described in terms of such damage". Athletes and dancers feel pain routinely in rehearsals, workouts, and competitions (Jacobs, Hincapiv \& Cassidy, 2012). A study with 1.365 teen amateur ballet dancers, and 900 adult professional ballet dancers revealed a rate of .99 and 1.09 injuries for every 1000 hours of dance, for male and female amateur dancers, respectively. Of these total injuries, $75 \%$ happened due to excess in exercise. Among the professional dancers, the rate was from 1.06 to 1.46 injuries for every 1.000 hours of dance for males and females, respectively. In this population, $64 \%$ of injuries were due to excessive exercising (Smith et al., 2015).

Even with this stressful panorama, there are no instruments in Sport Psychology that evaluate how adolescent dancers deal with the "pain" stressor, so present in their daily lives. A few studies reveal instruments in regard to coping in athletes, specifically for physical capacities (Goudas, Theodorakis \& Karamousalidis, 1998; Yan \& Mok, 2012). However, there are no specific questionnaires and scales to measure pain coping in dancers. Instead dancers are typically given inventories made for athletes or on the contrary for people who are not physically active (Anderson \& Hanrahan, 2008; Encarnación, Meyers, Ryan \& Pease, 2000).

Dancers are different from athletes due to qualities and aptitudes that make them artists, because they have to follow a specific technique allied to demonstration of expressivity and have an all prepared body (Guarino, 2015). Thereof, dancing demands physical abilities and athletic training because of elaborate movements performed in a pre-determined rhythm by the music. Professional dancers dedicate themselves wholly to this practice, overloading body structures. 
Generally, dancers begin when they are children compromising part of their development. Consequently, pain is a part of daily training and it is as if it belongs to the dancers (Singh, 2011).

Perroni (2007), Jacobs, Hincapiv and Cassidy (2012) and Smith et al. (2015) affirm that injuries occur in greater quantity due to practice overload and the non-compliance of necessary pauses to recuperate from the injuries. Dancers who remain constantly in pain and face stressful situations such as demands for good performances and the actual competitions suffer burnout symptoms because professional requirements exceed their response capacities (Costa, Pires, Ferreira Filho \& Noce, 2014; Cumming \& Duda, 2012). Many dancers continue to dance feeling chronic pain for fear of losing their positions in the dance companies (Byhring \& Bo, 2002). Nilsson, Leanderson, Wykman \& Strender (2001) report that dancers employed in companies for more than a year presented $95 \%$ of those injuries during that actual study period.

Generally, dancers do not feel differences between performance pain and pain injury and do not change their coping strategies according to the characteristics of the pain felt (Anderson \& Hanrahan, 2008). The study of coping is relevant mainly because it is the most consistent predictable variable in terms of psychological well-being (Compas, Connor-Smith, Saltzaman, Thomsen \& Wagsworth, 2001). Coping is associated to fatigue, sleep disorders, anxiety and depression affecting quality of life, relationships and school performance of these professionals, especially when the age of adolescence is taken into account (Forgeron \& King, 2013; Groenewald \& Palermo, 2015). Adolescent dancers, when introduced, specially, to the semiprofessionals are exposed to the aggravation of having to deal with the decision of following the career or not $(\mathrm{Li}, 2011)$, besides going through the typical organic and psychosocial changes of age (Cromer, 2011; Patara, 2010). In this context, painful conditions are maximized and may reveal little adaptive coping when dancers are faced with pain (Flink, Boersma \& Linton, 2013).

Although there are other concepts of coping, the present work adopts the Motivational Theory of Coping [MTC] proposed by 
Skinner and collaborators (Skinner, Edge, Altman \& Sherwood, 2003; Skinner \& Wellborn, 1994). As the instrument in this study was designed for adolescent dancers, the MTC was chosen as fundamental theoretical framework for being the most recent and for considering that the developmental level of the subject influences his/her coping abilities (Zimmer-Gembeck \& Skinner, 2011). The MTC comprehends coping as a regulatory action. Self-regulation is understood to be the capacity to self-monitor behavior in response to different situations, from knowledge of self and context (Sameroff, 2009). Therefore, coping is defined as an organizing process, which describes how people regulate their own behaviors, emotions and motivational orientation under stressful conditions (Skinner \& Wellborn, 1994). In adolescence, for example, the more common coping strategies are support-seeking, problem-solving and distraction (Zimmer-Gembeck \& Skinner, 2008); other authors also consider self-control, escape and avoidance (Persike \& Seiffge-Krenke, 2012; Persike \& Seiffge-Krenke, 2015; Seiffge-Krenke, 2013).

According to the motivational perspective, coping embodies individual efforts to maintain, restore and mend basic psychological needs of Relationships, Competence and Autonomy that are affected by stressful situations (Skinner \& Wellborn, 1994). These are understood to be universal, innate and evolutionarily (Deci \& Ryan, 2000). The first - need of Relationship or belonging (Relatedness) - refers to the close relationships and feeling safe and connected as well as having high self-esteem and the capacity to love. The need for Competence is about being effective in interactions with surroundings, obtaining positive results and avoiding negative ones. As for the need for Autonomy, it is related to capacity of choice (Skinner \& Wellborn, 1994).

The MTC also differentiates coping resources, which refer to what is available for the individual to deal with the stressor and the consequences of coping that explain the short-term and long-term effects of coping. Therefore, antecedents and consequences of coping strategies should be differentiated (Skinner \& Wellborn, 1994). From an extensive systematic review upon the scientific production of 20 years, selecting 
100 articles from the field, Skinner et al. (2003) identified more than 400 categories of coping. The authors classified these coping strategies in a hierarchical structure, distinguishing levels in which coping responses, coping strategies and adaptive processes relate to themselves.

At the system base (lowest level), are the "instances of coping" or "coping behaviors" that are responses of the individual to deal with stressful situations and are generally composed of coping scales. On the next level are the "ways of coping", a categorization of coping behaviors from their proposal, meaning or functional value. At the highest level, are the "families of coping", which are coping classifications that link to the adaptive processes and are multidimensional and multifunctional (Skinner et al., 2003).

In total, the authors identified 12 coping families as most frequent and well defined, related to challenge perception: Self-Reliance/ Self-Comforting, Support-Seeking, Problem-Solving, InformationSeeking, Accommodation and Negotiation; or to threat perception: Delegation, Social Isolation, Helplessness, Escape, Submission and Opposition. Each coping family represents a class of organized preoccupations in action response patterns directed to the self (oneself) as well as to the context. Therefore, each coping family group contains diverse ways of coping, whether they are behaviors, emotions or motivational orientations, with the same function relating the similar adaptive processes. For example, ways of coping related to the families of Problem-Solving, Helplessness and Escape serve to coordinate adaptive actions and contingences in the surroundings. To coordinate reliance and available social resources, people may present ways of coping related to coping families of Self-Reliance/Self-Comforting, Support-Seeking, Delegation and Social Isolation. Lastly, Accommodation, Negotiation, Submission and Opposition families serve to coordinate adaptively preferences and available options. The Motivational Theory of Coping (MTC) has been applied in research in Brazil (ex.: Motta \& Enumo, 2010; Oliveira, Enumo \& Paula, 2017; Ramos, Enumo \& Paula, 2015), however it is the first time to be used focusing Sport Psychology. 
Studies on pain coping evaluation have considered that Accommodation is only valid when the patient has control over the situation (Lauwerier et al., 2012; Van Damme, Crombez \& Eccleston, 2008). For these same authors, social support is adaptive when it enables a person to cope. Continued attempts to control or solve the problem of pain, when the effective control is low, results in fear, preoccupation, catastrophic thought and hypervigilance, which are adaptive for the short term but maladaptive for the medium and long terms (Crombez, Eccleston, De Vilger, Van Damme \& Clereq, 2008; Flink, Boersma \& Linton, 2013). Given the above, it is necessary to measure types of coping strategies of dancers dealing with pain, as well as their adaptive function so that only then may it be possible to design an intervention aimed to revert the pain condition. Despite advances in the field, there are no instruments that assess pain coping in Brazil validated for dancers. Therefore, the present study aimed to create the Scale of Coping with Pain for Dancers (COPAIN-Dancer), based on the Motivational Theory of Coping and test for its validity (Skinner et al., 2003; Skinner \& Wellborn, 1994).

\section{Methods}

\section{Participants}

The convenience sampling of the present study was composed of 386 male and female dancers (93.42\% female), aged 10 to $19(M=$ $15.35, \mathrm{SD}=3.36)$. Participants had been dancing, on average for 7.85 years $(\mathrm{SD}=3.75)$. Socioeconomic status was, on average classified as C1 (gross family monthly income - \$631.56).

\section{Measures}

The Scale of Coping with Pain for Dancers (COPAIN-Dancer) was based on the Motivational Theory Coping (MTC) (Skinner et al., 2003; Skinner \& Zimmer-Gembeck, 2016; Skinner \& Wellborn, 1994). Items on coping with pain in the dance context were elaborated for each of the 12 families of coping - Self-Reliance/Self-Comforting, 
Support-Seeking, Problem-Solving, Information-Seeking, Accommodation and Negotiation (adaptive families) and Social Isolation, Escape, Opposition, Delegation, Helplessness and Submission (maladaptive families). The COPAIN-Dancer is a self-report scale, considering that from age three, it is possible to obtain an oral report, written or nonverbal describing thoughts, feelings, and actions related of pain (Von Baeyer, 2013). It is important to highlight that one of the authors has 22 years of experience as a dancer and eight years, as a dance teacher.

Socioeconomic status of participants was assessed by the Economic Classification Criteria - Brazil/Critério de Classificação Econômica - Brasil (Associação Brasileira de Empresas de Pesquisa, 2013). Individuals are classified by the number of item points and categorized based on a cut-off line, therefore yielding seven levels: A, B1, B2, C1, C2, D, E. Level "A" in the most economically favored in terms of purchasing power (average gross monthly income = US\$7367.82) and level "E", is considered the least favored (gross monthly income $=$ US\$271.89).

\section{Procedure and data analysis}

The author followed the ethical principles of psychologists and code of conduct as recommended by the APA. The project was previously approved by the Ethics Committee in Research at the Pontifícia Universidade Católica de Campinas, São Paulo State, Brazil (Protocol n. 465.153), under regulations of the Brazilian National Health Council/ Conselho Nacional de Saúde. Participants were selected from national and international dance festivals in Brazil according to their availability to take part in the study. Parents or guardians were informed about the objectives, methodology, risks and benefits of the study. They voluntarily participated after reading and signing formal written consent. Instruments were applied after stage rehearsals on the day of the competition.

Initially, the instrument was created based on Motivational Theory of Coping (Skinner et al., 2003; Skinner \& Wellborn, 1994), studies on pain in dancers and one of the researchers experiences in dance. 
The initial inventory was composed of 118 questions. Three experts in the MTC assessed these questions and classified each of them into 12 families of coping presented in the Introduction. After analyses of evaluators and their comparisons by Kappa, 36 questions remained, three for each family of coping, divided in behavior, emotions and orientation as proposed by MTC (Skinner et al., 2003). Lack of intr.-evaluator agreement (Fleiss's Kappa $=.49$ ) was due to the difficulty in classifying the items in the families of coping and classifying them as behavior, emotions and motivational orientation.

After the construction phase, the procedure proposed by Pasquali (2004) was adopted. Analysis of instrument items was performed by five evaluators (two Portuguese teachers, one specialist in Sport Psychology and two dance specialists) to observe semantic analysis (item comprehension) and their pertinence. For this, a protocol adapted from Balbinotti, Benetti and Terra (2007) was used to assess clarity of language and practical meaning. In the observational field, the judges were able to point out flaws, they suggested correction or even the exclusion of determined items. Judges used a five-point scale to evaluate language clearness and relevance (one being for "very little clear language" and five for "very much clear language", one for "very little relevant" and five for "very much relevant"). Then the Content Validity Index (CVI) was calculated for clarity of language and practical meaning proposed by Hernández-Nieto (2002).

Kappa was used to assess the theoretical dimension of the instrument among judges. Necessary corrections were performed. Data was processed, and statistical analysis performed. Firstly, considering the objectives of this study, the number of factors to be maintained in EFA was verified based on parallel analysis (Hayton, Allen\& Scarpello, 2004; Watkins, 2006). The $\mathrm{R}$ software (version 2.15.3) was used because of the possible of parallel analysis for polychoric correlations. MPlus software (version 6.12) was used for EFA and ESEM with polychoric correlations, and EFA, using Pearson (components and main axes). After establishing the most adequate factor structure reliability coefficients for internal consistence (Cronbach alpha). 
As ESEM revealed an inadequate structure in terms of psychometric values, the items should have been excluded. However, in practice, items present great relevance and their exclusion would be harmful for pain coping assessment. A possible explanation for these low figures is the practical and theoretical disagreement. One example may be "negotiation with a teacher to do lighter trainings because of pain" is theoretically considered to be adaptive (Negotiation coping family) but in practice it becomes maladaptive because consequences will be more negative than positive such as having to leave dance to take care of the pain. Accordingly, the scores end up being low. Therefore, option for Item Theory Response (ITR) and Network Analysis was made to verify the actual necessity for excluding the items or soaking them for their practical relevance and inversion of the psychological function for this population.

To confirm design results, a more robust IRT method was selected because it evaluates each item separately using the Rasch model (Wright \& Masters, 1982). (Wright \& Masters, 1982). Network Analysis which represents the standard association of variables in a bidimensional graphic object was also used (Epskamp, Cramer, Waldorp, Schmittmann\& Borsboom, 2012).

Representation is formed by nodes and lines, which equate the analyzed variables and relations among them, respectively. Disposition of variables is defined by Fruchterman-Reingold algorithm (Fruchterman \& Reingold, 1991), so that: a) related variables are attracted and non-related, pulled out; b) the more central a variable, the more related it is to the rest c) lines represent the pondered association among the nodes, positive being green and negative, red. Correlation and partial correlations networks were analyzed (controlling for the multivariate effect), $r^{2}$ - pondered effect measurement. The graphical Least Absolute Shrinkage and Selection Operator (LASSO) was used for the partial correlation estimation method (Friedman, Hastie\& Reingold, 2008), and the Extended Bayesian Information Criterion (EBIC) (Chen \& Chen, 2008). Measures of Central Tendency were performed: Betweenness, which represents variables that most present 
"bridges" to other; Closeness, is measured by the inverse of the distances form one node to all the others; Strength, indicates the largest correlation forces (Machado, Vissoci \& Epskamp, 2015).

These methodological differences were thought of because factor analysis presumes that one or more groups of items may be explained by one or more groups of latent variables (Hauck Filho \& Zanon, 2015). Whereas, network analysis has a different presumption, in which there are no latent variables, just a dynamic structure of variables in a system (Machado et al., 2015). Therefore, considering the diverse methodological processes, it can be determined if an instrument is adequate to be used and which is the best organization for it in terms of factors.

\section{Results}

\section{Content Validity Evidence}

Content validity coefficients for language, practical meaningfulness and theoretical meaningfulness were considered greater than .80. Five items were excluded: i29."I use ointments and pain and anti-inflammatory medicine" and i36."I don't decrease the amount of exercise because of perfectionism and persistence, while I could do it" due to the inadequate language, presenting .76 and .56 coefficients, respectively; and two items - i6."I pray" and i73. "I know I can ask for something to make the pain better" due to low practical meaningfulness (.67 and .76, coefficients, respectively); and i20."I seek a nutritionist" due to low theoretical pertinence (.76 coefficient).

In regard to the 118 items, validity coefficient for language was .87; for practical pertinence, .94; and for theoretical meaningfulness, .95, which were considered to be good results. Fleiss's Kappa showed the following results for intra-evaluator agreement: theoretical meaningfulness (.81), practical pertinence (.87) and language (.92), considered to be excellent. However, it was necessary to exclude more items because of intra-judge agreement in the families of coping (MTC proposal) - of the 118 items (Fleiss's Kappa $=.49$ ), only 36 were left. 


\section{Validity Evidences based on internal structure}

\section{Factor Analysis and Parallel Analysis}

To determine factor solution, parallel analysis was initially undertaken (Hayton, Allen \& Scarpello, 2004; Watkins, 2006) by R software (2.15.3 version). Analysis suggested a 6-component solution (in the case of main component analysis) and 10 factors (for the case of factor analysis). Analysis for main components was run on SPSS (17 version), with 6 components, and factor analysis for polychoric variables via Mplus (6.12 version), using 2, 3, 6, 9 and 10 factors.

Analyses performed pointed out a tendency to low magnitude of correlation among items which hampered the establishment of a factor solution. Despite low correlation, the 2-factor proposal was the best for theoretical explanation and therefore it was maintained. Table 1 presents component factor loads ran, based on the extracted factors and reliability by Cronbach's alpha.

Items with greater factor load for Factor 1 - Maladaptive Coping with Pain - were: i1. "I physically or verbally harm my dance colleague because I feel that I could lose the 'role' in the choreography because I am in pain" (.74); i32. "I think that I can't count on anyone and so I move away" (.549); i36. "I think about revenging my dance colleagues because they don't understand my pain" (.533). This indicates that the families of coping Opposition and Social Isolation are the worst for dancers because the heaviest loads were found in this factor. Additionally, it may suggest in these cases that the pain stressor is seen as a threat to context for Autonomy as well as for Relationship.

For Factor 2 - Adaptive Coping with Pain, the items which present greater factor loads were i15. "I feel that I can do something to make the pain better" (.543); i30."I think about setting priorities to take care of the pain" (.527); i16. "I am curious about alternative pain control techniques" (.513). Problem-Solving and Seeking-Information were highlighted in Factor 2 by factor analysis; in this case acting as a challenge to the need of Competence. 


\section{Table 1}

Factor loads of run components based on extracted factors and reliability Cronbach's alpha for the Scale of Coping with Pain for Dancers (COPAIN-Dancer)

\begin{tabular}{|c|c|c|c|}
\hline Items & $\begin{array}{l}\text { Factor 1- } \\
\text { Maladaptive } \\
\text { Coping }\end{array}$ & $\begin{array}{l}\text { Factor 2- } \\
\text { Adaptive } \\
\text { Coping }\end{array}$ & Explanations \\
\hline 1. I fully dedicate myself to dance. & & .254 & Factor load $<.30$ \\
\hline 2. I'm looking for an orthopedist or physical therapist. & & .301 & \\
\hline 3. I plan activities for the day that do not overload my body. & & .230 & Factor load $<.30$ \\
\hline 4. I seek information on what to do to decrease the pain. & & .471 & \\
\hline 5. I talk about other things to forget the pain. & & .348 & \\
\hline 6. I negotiate with the teacher to do lighter trainings. & .258 & & $\begin{array}{l}\text { Factor load }<.30 \\
\text { Inverted } \\
\text { function. }\end{array}$ \\
\hline $\begin{array}{l}\text { 7. I complain I have pain but I do nothing to change, } \\
\text { leaving my teacher to decide if I'll continue to dance or } \\
\text { not. }\end{array}$ & & .116 & $\begin{array}{l}\text { Factor load }<.30 \\
\text { Factor load }<.30 \\
\text { Compound } \\
\text { sentence. }\end{array}$ \\
\hline
\end{tabular}

8. I move away from my dance friends and from other friends because I have pain

9. Sometimes I forget the choreography when I have pain.

10. I ignore the tests to avoid the pain.

11. I think I am to blame for having pain.

.251 Inverted

12. I physically or verbally impair my dance partner because I feel I can lose the "role" in the choreography because I have pain.

13. I feel like everything will be fine.

14. I ask someone to tell me I will feel better or that the pain will decrease.

Load in more than one factor.

If remained in

$\mathrm{F} 1$, inverted

function

Compound sentence

15. I feel I can do something to improve the pain. 


\begin{tabular}{ccc}
\hline \multirow{2}{*}{ Items } & Factor 1- & Factor 2- \\
& Maladaptive & Adaptive \\
Coping & Coping & Explanations \\
\hline
\end{tabular}

16. I am curious about alternative techniques for pain management.

17. I accept trainings and rehearsals even with pain.

18. I believe I am not to blame for my muscular pain.

19. I am ashamed for having pain.

20. I feel alone, not able to share my pain

21. I feel there is no treatment for my pain

22. I feel scared when I have pain

23. I'm discontent with the pain.

Factor load $<.30$

.156 Inverted

function.

24. I think the teacher is to blame for my pain.

25. I tell myself that the pain does not touch me.

.288 Factor load $<.30$

26. When I receive greetings from teachers and colleagues, I believe that pain is worth it.

27. I think of stretching my legs.

28. I think of preventing pain with leisure and rest.

29. I am convicted that pain is part of the dance.

30. I think of setting priorities for pain management.

31. I think about letting the doctor decide if I can dance or not.

Factor load $<.30$

32. I think that I cannot count on anyone and then I move away.

33. I panic when I feel pain, thinking I cannot dance anymore.

34. I think of postponing my doctor's appointment to continue dancing.

Factor load $<.30$

171 Inverted

function.

Factor load < .30 and similar

35. When I am dancing, I think I will not be able to do some movement because I am going to feel pain. in more than one factor Compound sentence

36. I think of revenge on my dance partners because they do not understand my pain. 
The 12 families of coping were not statistically distinguished by means of factor analysis and parallel analysis. It is consistent to comprehend, however, if families are adaptive or maladaptive - the two factors found are explained by the MTC. As for instrument reliability, Cronbach's alpha was .69 for Adaptive Coping with Pain and .68 for Maladaptive Coping with Pain. Overall, an instrument or test is classified as reliable when the $\alpha$ is at least .70 (Nunnally, 1978). Therefore, this instrument was found to be marginally reliable. When the low factor load of items and not so satisfactory precision values were observed by EFA, an IRT solution using the model of Rasch was sought.

\section{Item Response Theory (IRT)}

For IRT, analysis was performed considering the two divisions (Factor 1 and Factor 2). Both presented Infit e Outfit values as expected, that is, up to 1.5 (Linacre, 2014) and some items presented a higher level of discrimination because they revealed infit lower than 8 (Linacre, 2014), as for i19. "I am ashamed of being in pain", i9."Sometimes I forget the choreography when I am in pain", i1."I dedicate myself fully to dance", for Factor 1; and i4."I seek information on what to do to decrease the pain" and i3."I plan activities for the day that do not overload my body" for Factor 2. It is important to highlight that items that respondents could oscillate on the theta scale were fixed, so a normative table was created for this population (Appendix). Considering these results, it was found that although factor loads were low by Infit and Outfit values (Table 2), the items might be maintained. In search of greater confirmation of the psychometric properties, analysis was continued, using Network Analysis, as detailed below.

\section{Network Analysis}

It is important to emphasize that for network analysis it was necessary to exclude only item i12."I physically or verbally harm my dance colleague because I feel that I could lose the 'role' in the choreography because I am in pain". This item was excluded due to 


\section{Table 2}

Infit and Outfit item difficulty and adjustment of Scale of Coping with Pain for Dancers (COPAIN-Dancer)

\begin{tabular}{|c|c|c|c|c|c|c|c|}
\hline \multicolumn{4}{|c|}{ Factor 1 - Adaptive Coping with Pain } & \multicolumn{4}{|c|}{ Factor 2 - Maladaptive Coping with Pain } \\
\hline Item & $\delta$ & Infit & Outfit & Item & $\Delta$ & Infit & Outfit \\
\hline $\mathrm{I} 11$ & .96 & 1.26 & 1.34 & $\mathrm{I} 12$ & 1.17 & 1.36 & .97 \\
\hline I02 & .70 & .84 & .89 & $\mathrm{I} 36$ & .63 & 1.48 & .98 \\
\hline I03 & .43 & .90 & .92 & I08 & .43 & 1.11 & 1.08 \\
\hline $\mathrm{I} 34$ & .40 & 1.23 & 1.22 & $\mathrm{I} 32$ & .37 & 1.05 & .93 \\
\hline I05 & .31 & .97 & .96 & I19 & .27 & 1.06 & .89 \\
\hline I16 & .29 & 1.00 & 1.00 & I10 & .26 & .79 & .79 \\
\hline $\mathrm{I} 30$ & .28 & .75 & .75 & $\mathrm{I} 20$ & .10 & 1.11 & .90 \\
\hline $\mathrm{I} 25$ & .26 & 1.05 & 1.05 & $\mathrm{I} 21$ & .00 & 1.01 & .98 \\
\hline I07 & .22 & 1.31 & 1.36 & I24 & -.02 & 1.29 & 1.23 \\
\hline $\mathrm{I} 28$ & .06 & .99 & 1.02 & $\mathrm{I} 31$ & -.09 & 1.12 & 1.24 \\
\hline I18 & .03 & 1.22 & 1.28 & I09 & -.25 & .73 & .81 \\
\hline $\mathrm{I} 23$ & -.04 & 1.17 & 1.19 & I06 & -.38 & 1.20 & 1.25 \\
\hline I04 & -.06 & .93 & .92 & I14 & -.46 & 1.16 & 1.26 \\
\hline $\mathrm{I} 13$ & -.24 & .99 & .98 & $\mathrm{I} 33$ & -.53 & 1.11 & 1.09 \\
\hline I15 & -.28 & .70 & .70 & $\mathrm{I} 22$ & -.57 & .94 & .92 \\
\hline $\mathrm{I} 27$ & -.58 & .96 & .99 & $\mathrm{I} 35$ & -.94 & .90 & .99 \\
\hline I01 & -.60 & .66 & .68 & & & & \\
\hline $\mathrm{I} 17$ & -.65 & 1.02 & 1.03 & & & & \\
\hline I29 & -.66 & 1.08 & 1.06 & & & & \\
\hline I26 & -.82 & 1.00 & .89 & & & & \\
\hline
\end{tabular}

it appeared constantly, showing no significant variance, as the dancers responded in a very similar way.

Using correlation analysis, it is possible to observe clusters between adaptive coping on one side and maladaptive coping on the other (Figure 1). Some items, however, presented different functions than in theory even though they were grouped in different factors, they were positioned near the opposites and presented positive correlations.

Network analysis by partial correlations was undertaken, as they presented greater control over variances (Figure 1). LASSO penalty indicates 
low correlations transform into zero, permits only the most significant correlations and provides more illustrative graphs. It is valid to note that for the partial correlations, values higher that 0.1 are already considered significant because partial correlations exclude the effects of relations between a third variable, in the relation between the two of them.

For network analysis it is possible to verify a strong positive relation with a greater concentration of variables and representing the higher correlations between items related to maladaptive families of coping such as Delegation, Social Isolation, Helplessness and Opposition, in which pain is seen as a threat to the three basic psychological needs - Autonomy, Competence and Relatedness:

i19. "I'm ashamed to be in pain" (Self-pity, Delegation-Relatedness); i20. "I feel alone, not able to share my pain" (Social Isolation- Relatedness);

i32. "I think that I can't count on anyone and so I move away" (Social Isolation- Relatedness) (stronger relations with i.20);

i21. "I feel there is no treatment for my pain" (Helplessness - Competence);

i36. "I think about getting revenge on my dance colleagues because they don't understand my pain" (Opposition - Autonomy) (stronger relations with 1.32) (Figure 1-graph 2).

On the other extreme, there was a strong positive relation among the four items relative to the coping families of Problem-Solving and Information-Seeking indicating a challenge to the need of Competence:

i30. "I think about setting priorities to take care of the pain" (Problem-Solving);

i28. "I think about preventing the pain with leisure activities" (Problem-Solving);

i16. "I am curious about alternative pain control techniques" (Information-Seeking);

i4. "I seek information to be able to decrease the pain" (Information-Seeking (Figure 1). 

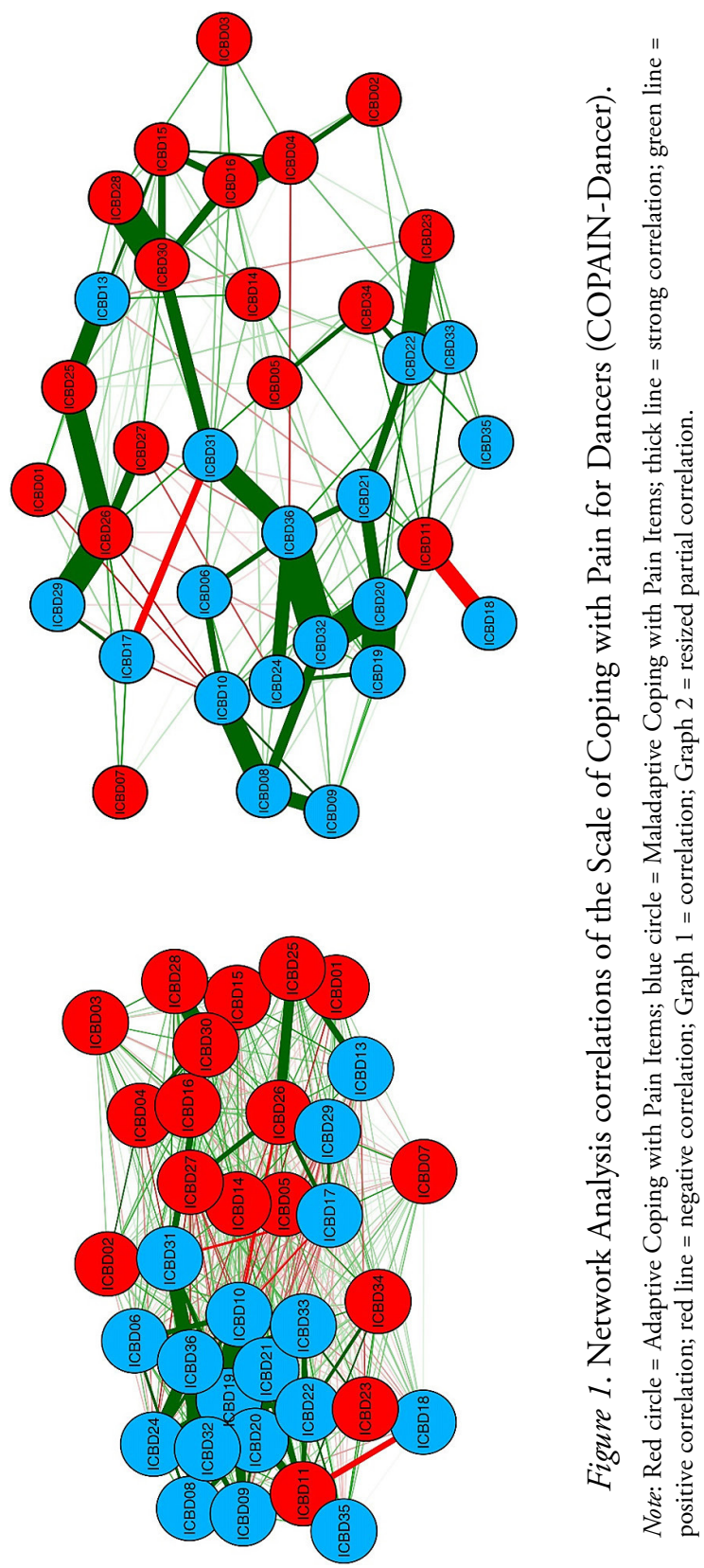
These results are similar those presented by Exploratory Factor Analysis (EFA) via ESEM.

In addition to, the relations above other groupings may be observed on Figure 1, showing strong positive correlations between these families of coping:

a) Social Isolation, Helplessness and Escape, respectively:

i8. "I move away from my dance friend and from other friends because I am in pain";

i9. "Sometimes I forget the choreography when I am in pain";

i10. "I skip rehearsals to avoid pain";

b) Delegation and Opposition:

i31. "I think about letting my doctor decide if I can dance or not"; i36. "I think about revenging my dance colleagues because they don't understand my pain";

c) Accommodation and Support-Seeking:

i29. "I am convicted that pain is part of dancing";

i26. "When I receive compliments from teachers and colleagues, I believe that pain is worth it";

d) Escape and Submission:

i22. "I am scared when I am in pain";

i23. "I'm discontent with the pain";

e) Self-Reliance/Self-Comforting and Support-Seeking:

i25. "I say to myself that the pain doesn't get to me";

i13. "I feel that everything is going to be alright";

i26. "When I receive compliments from teachers and colleagues, I believe that pain is worth it".

On the other hand, there was a strong negative correlation between items related to:

a) Submission and Negotiation, respectively:

i11. "I think I'm the one to blame for being in pain";

i18. "I believe that I am not blame for my muscular pain";

b) Accommodation and Self-Reliance/Self-Comforting:

i17. "I accept my trainings and rehearsals even in pain"; 
i25. "I say to myself that the pain doesn't get to me";

As seen in the network analysis (Figure 1 - graph 2), it is possible to discern that three items remained isolates, presenting little relations to the rest:

i3. "I plan activities that do not overload my body for the day" (Problem-Solving - Competence);

i7. "I complain I'm in pain, but I don't do anything to change, leaving my teacher to decide if I continue to rehearse or not" (Delegation - Relatedness);

i35. "When I am dancing, I think that I won't be able to do any movements because I will feel pain” (Helplessness - Competence) (Figure 1, graph 2).

To investigate the item cluster structure in the ICDB item network, the spin glass algorithm with "igraph" $\mathrm{R}$ package was applied. Item cluster in the network analysis context is called "community" and means subsets of nodes based on their interrelations. Spinglass method is preferred when there is positive and negative item links, and its community-finding algorithm is based on statistical mechanics, named annealing of spin glasses, comparing the actual graph modularity with simulated ones (REF). In this model, nodes subsets are expected to have many positive links inside the group and negative links among subsets. When applied to the present data, spin glass algorithm revealed two communities, with an modularity value of -47.53 and membership vector of $v=[1,1,1,1,1,2,2,2,2,2,2,1,1,1,1,1,1,2,2,2,2,2$, $2,1,1,1,1,1,1,2,2,2,2,2,2]$, endorsing the same structure found in the factor analysis (Reichardt \& Bomholdt, 2008).

This is consistent with the EFA by ESEM, as these items present very low factor loads. A possible explanation for this is that the items are composed, having more than one command in the same phrase and may have confused participants. 


\section{Discussion}

Results demonstrated the possibilities of analysis in a pain coping scale for adolescent dancers - the COPAIN-Dancer, based on the Motivational Theory of Coping (Skinner et al., 2003; Skinner \& Wellborn, 1994). Initially, the authors found difficulty in classifying emotions, behaviors and motivational orientations in the 12 families of coping by the MTC. There is a complexity in the coping construct analyzed by the MTC, as various aspects are relevant to be detailed by functional analysis. Also, when creating a very specific instrument, aimed toward pain coping in adolescent dancers, it is necessary to consider the practical pertinence of the items (Silva et al., 2015), their representability to assess the construct in question (McCann, Jowdy \& Van Raalte, 2011; Peixoto \& Nakano, 2014); and adolescent developmental characteristics (Kistensen, Schafer \& Busnello, 2010; Zimmer-Gembeck \& Skinner, 2008; Zimmer-Gembeck \& Skinner, 2011). It is also necessary to verify the outcome of these actions, that is, if such attitude helped alleviate or not the pain (McGrath et al., 2008; Vowles, McCraken, Sowden \& Ashworth, 2014; Zempsky et al., 2014). Due to the methodological difficulty mentioned, many of the items originally developed $(n=118)$ were not included in the final version for psychometric assessment $(\mathrm{n}=36)$. In addition, divergences between used psychometric statistics were found.

What stands out is the fact that classical statistical methods were not efficient in detecting conceptual and qualitative detailed analysis, as proposed by MTC. This might explain the low factor loads found for each or each one of 12 families of coping. Therefore, it was only possible to classify the instrument in two factors - Adaptive Coping with Pain and Maladaptive Coping with Pain - disregarding statistically all other possibilities that the instrument provides. This was similar to when some authors attempted to create tools to assess coping as proposed by MTC, because they were not able to divide the 12 families of coping or their functional classifications; finding only differences between adaptive and maladaptive families of coping (Justo, 2015; Lees, 2007). 
Comparing the responses of psychological assessment of pain coping in adolescent dancers with their practice activities (interventions in Sport and Physical Activity Psychology with this population), theoretical distinction from practice can be found for some coping behavior. An example is the "negotiating with the teacher to make lighter practices," or "avoid going to the doctor." Theoretically, these are understood as maladaptive coping, since, if maintained for long periods, will be detrimental to health. However, these situations are extremely threatening for the dancers as they may be excluded from the group and stay a long time from dancing. Therefore, avoiding these situations ends up having an adaptive psychological function, since the opposite would be much worse.

This illustrates how important it is to develop specific psychological assessment instruments for each population, as there may be different mental functions. Also, if the analysis is based on one statistical method, for example, the Classical Test Theory (CTT), the instrument would have 31 items instead of 36 losing very relevant items. Thus, considering the theoretical-methodological and practical relevance, only item 12 warrants exclusion. Therefore, it is important to not just use one statistical method and exclude items which are very significant. A multiple composition of statistical tests allows for a more robust and accurate analysis in psychometric terms (Pacico \& Hutz, 2015).

Qualitatively, by observation on how individuals responded to the question "To what extent, what you did helped you?" on the postcoping questionnaire, which aimed to complement the second column of the instrument, it was found that younger adolescents (10-12 years) misunderstood the item. Therefore, it was felt, that this question required a certain maturity of the respondents or explanation by the applicator. A suggestion for clearness could be: "To what extent, what you did helped you decrease the pain, on the same line for each item". Another alternative would be to apply this instrument assisting individually and not collectively all teenagers from 10-12 years. Finally, this tool could be used for adolescents only over 12 years. 
The second part of the instrument, which evaluates post-coping, is very important as it has a dual function - as well as pain coping assessment it unleashes a self-reflection process on the coping used, thus initiating a psychoeducational intervention. Before intervention, actual assessment should be evaluated as evaluation itself generates reflections that can trigger positive changes. It is well understood that the great importance of this study is for health, well-being and performance of the dancers. After all, when pain coping improves, it is understood that there may be a reduction in pain levels and this improves overall health and performance in dance.

\section{Conclusion}

The present study reached the proposed aim to construct and verify validity evidences for the Scale of Coping with Pain for Dancers (COPAIN-Dancer), based on the Motivational Theory of Coping (MTC). The instrument showed a tendency to low correlation between items and Cronbach's alpha quite close to the recommended minimum, which was enhanced with the division of the instrument into two factors (adaptive pain coping strategies and maladaptive pain coping strategies).

The different statistical methods showed that if only one statistical analysis were used (CTT), items of great practical relevance would be excluded. Having adopted a more robust procedure, the instrument kept its theoretical and methodological psychometric properties and preserved practices. Only one item (item 12) was needed to be deleted.

It was observed that the traditional statistical methods are inefficient to distinguish the complexity of functional analysis in pain coping, minimizing the instrument's potential (analysis of the 12 families of coping), as observed in other studies in the literature. However, IRT and Network Analysis were able to support the relevance of the items in a practical and systemic fashion.

Further research is suggested so that the psychometric properties of the instrument may be confirmed. The present study had some 
limitations such as the different modalities of dance and the fact they were from one single country, Brazil, and single context (only dancers attending dance festivals completed inventories). However, due to the preliminary results of this study, it seems imperative for the making of international collaborations as to widen the scope of the instrument into other languages, besides the Portuguese and provide other countries specific coping with pain instruments for dancers.

This instrument is recommended to be administered to adolescents over 12 years due to the cognitive maturity necessary to respond to the instrument items. Assisted format, preferably individual, may be adopted, considering that participants would feel more at ease to ask questions if they were alone with interviewer. It is assumed, therefore, despite all explanations verbalized on confidentiality and ethical aspects, participants still fear that the information they provided might be used against them, being transmitted to teachers and testers. Therefore, it is imperative to emphasize that no one but the researchers have access to information from instruments, when studies are published. In case of assessment for structuring psychological intervention is done, only the psychologists should know the answers given by dancers. Finally, analyses performed on the Scale of Coping with Pain for Dancers (COPAIN-Dancer) revealed that the instrument may be considered for adolescents.

It is important that further studies aiming to construct and validate specific instruments for the population desired to be analyzed, be aware of the type of practiced activity, age, cognitive aspects and level of sports performance (amateur or professional), as there are significant differences that may influence the results.

\section{References}

Anderson, R. \& Hanrahan, S. J. (2008). Dancing in pain: Pain appraisal and coping in dancers. Journal of Dance Medicine \& Science, 12(1), 9-16. [PMID:19618573] 
Associação Brasileira de Empresas de Pesquisa - ABEP. (2013). Critério de Classificação Econômica Brasil [Economic Classification Criteria - Brazil]. São Paulo: ABEP. Retrieved from: http://www. abep.org/novo/Default.aspx

Balbinotti, M. A., Benetti, C. \& Terra, P. R. S. (2007). Translation and validation of the Graham-Harvey survey for the Brazilian context. International Journal of Managerial and Finance, 3(1), 26-48.

Byhring, S. \& Bo, K. (2002). Musculoskeletal injuries in the Norwegian National Ballet: A prospective cohort study. Scandinavian Journal of Medicine and Science, 12(6), 365-370. https://doi. org/10.1034/j.1600-0838.2002.01262.x

Chen, J. \& Chen, Z. (2008). Extended Bayesian information criteria for model selection with large model spaces. Biometrika, 95(3), 759-771. https://doi.org/10.1093/biomet/asn034

Compas, B. C., Connor-Smith, J. K., Saltzaman, H., Thomsen, A. H. \& Wagsworth, M. E. (2001). Coping with stress during childhood and adolescence: Problems, progress, and potential in theory and research. Psychology Bulletin, 127(1), 87-127. https://doi.org/10.1037//0033-2909.127.1.87

Costa, V. T. D., Pires, D. A., Ferreira Filho, E. \& Noce, F. (2014). Analysis of burnout syndrome in ballet dancers. Revista de Educação Física/UEM, 25(2), 163-171. https://doi.org/10.4025/ revedfis.v2512.23286

Crombez, G., Eccleston, C., De Vileger, P., Van Damme, S. \& Clereq, A. (2008). Is it better to have controlled and lost than never to have controlled at all? An experimental investigation of control over pain. Pain, 137(3), 631-639. https://doi.org/10.1016/j.pain. 2007.10.028

Cromer, B. (2011). Adolescent development. In K. R. Stanton, B. S. Geme, N. Schor \& B. R. Saunder. Nelson Textbook of Pediatrics (19 ${ }^{\text {th }}$ ed., pp. 649-659). Philadelphia: Elsevier Health.

Cumming, J. \& Duda, J. (2012). Profiles of perfectionism body-related concerns and indicator of psychological health in vocational dance students: An investigation of $2 \times 2$ model of perfectionism. 
Psychology of Sport and Exercise, 13(6), 729-738. https://doi. org/10.1016/j.psychsport.2012.05.004

Deci, E. L. \& Ryan, R. M. (2000). The "what" and "why" of goal pursuits: Human needs and self-determination of behavior. Psychological Inquiry, 11(4), 227-268. https://doi.org/10.1207/ S15327965PLI1104_01

Encarnación, M. L. G., Meyers, M. C., Ryan, N. D. \& Pease, D. G. (2000). Pain coping styles of ballet performers. Journal of Sport Behavior, 23(1), 20-32. https://doi.org/10.1097/00005768199905001-01015

Epskamp, S., Cramer, A. O. J., Waldorp, L. J., Schmittmann, V. D. \& Borsboom, D. (2012). Qgraph: Network visualizations of relationships in psychometric data. Journal of Statistical Software, 48(1), 1-18. https://dx.doi.org/10.18637/jss.v048.i04

Flink, I. L., Boersma, K. \& Linton, S. (2013). Pain catastrophizing as repetitive negative thinking: A development of the conceptualization. Cognitive Behavioral Therapy, 42(3), 215-223. https:// dx.doi.org/10.1080/16506073.2013.769621

Forgeron, P. \& King, S. (2013). Pain, social relationships, and school. In P. J. McGrath, B. J. Stevens, S. M. Walker \& W. T. Zempsky (Eds.), Oxford Textbook of Paediatric Pain (pp. 1-17). Oxford: Oxford University Press. https://dx.doi.org/10.1093/ $\mathrm{med} / 9780199642656.003 .0013$

Friedman, J., Hastie, T. \& Tibshirani, R. (2008). Sparse inverse covariance estimation with the graphical lasso. Biostatistics, 9(3), 432-441. https://dx.doi.org/10.1093/biostatistics/kxm045

Fruchterman, T. M. J. \& Reingold, E. M. (1991). Graph drawing by force-directed placement. Software: Practice and Experience, 21(11), 1129-1164. https://dx.doi.org/10.1002/spe.4380211102 Goudas, M., Theodorakis, Y. \& Karamousalidis, G. (1998). Psychological skills in basketball: Preliminary study for development of a Greek form of the Athletic Coping Skills Inventory-28. Percptual and Motor Skills, 86(1), 59-65. https:// doi.org/10.2466/pms.1998.86.1.59 
Groenewald, C. B. \& Palermo, T. M. (2015). The price of pain: the economics of chronic adolescent pain. Editorial. Pain Management, 5(2), 61-64. https://doi.org/10.2217/pmt.14.52

Guarino, L. (2015). Is dance a sport? A twenty-first-century debate. Journal of Dance Education, 15(2), 77-80. https://doi.org/10.10 80/15290824.2015.978334

Hauck Filho, N. \& Zanon, C. (2015). Questôes básicas sobre mensuração [Basic questions about measurement]. In C. S. Hutz, D. R. Bandeira \& C. M. Trentini (Orgs.). Psicometria [Psychometry] (pp. 23-44). Porto Alegre: Artmed.

Hayton, J. C., Allen, D. G. \& Scarpello, V. (2004). Factor retention decisions in exploratory factor analysis: A tutorial on parallel analysis. Organizational Research Methods, 7(2), 191-205. https://dx.doi.org/10.1177/1094428104263675

Hernandiez-Nieto, R. A. (2002). Contributions to statistical analysis. Mérida: Universidad de Los Angeles.

International Association for the Study of Pain (IASP). (2016). Pain. IASP Terminology. Retrieved from: http://www.iasp-pain.org/ Education/Content.aspx?ItemNumber=1698\#pain

Jacobs, C. L., Hincapiv, C. A. \& Cassidy, J. D. (2012). Musculoeskeletal injuries and pain in dancers: A systematic review update. Journal of Dance Medicine \& Science, 16(2), 74-84. Retrieved from: https://www.ingentaconnect.com/contentone/jmrp/jdms/ 2012/00000016/00000002/art00003;jsessionid =6av8e7ol36p b0.x-ic-live-01

Justo, A. P. (2015). Autorregulação nos adolescentes: Relaçôes entre estresse, enfrentamento, temperamento e problemas emocionais e de comportamento [Self-regulation in adolescents: Relations among stress, coping, temperament and emotional and behavioral problems]. Doctorate Thesis, Pontifícia Universidade Católica de Campinas, Campinas, SP, Brazil. Retrieved from: http:// tede.bibliotecadigital.puc-campinas.edu.br:8080/jspui/handle/ tede/469 
Kistensen, C. H., Schafer, L. S. \& Busnello, F. B. (2010). Estratégias de coping e sintomas de stress na adolescência [Coping strategies and stress symptoms in adolescence]. Estudos de Psicologia (Campinas), 27(1), 21-30. https://dx.doi.org/10.1590/S0103166X2010000100003

Lauwerier, E., Van Damme, S., Goubert, L., Paemeleire, K., Devulder, J. \& Crombez, G. (2012). To control or not? A motivational perspective on coping with pain. Acta Neurologica Belgica, 112(1), 3-7. https://dx.doi.org/10.1007/s13760-012-0020-6

Lees, D. C. (2007). An empirical investigation of the Motivational Theory of Coping in middle to late childhood. Doctoral Thesis. Griffith University, QLD, Australia. Retrieved from: https://www120. secure.griffith.edu.au/rch/items/00104138-8f7b-615f-9719$4 \mathrm{~d} 6757976 \mathrm{~b} 28 / 1 /$

$\mathrm{Li}, \mathrm{Z}$. (2011). Adolescent males in dance: A closer look at their journey. Journal of Physical Education, Recreation and Dance, 82(7), 17-23. https://dx.doi.org/10.1080/07303084.2011.10598653

Linacre, J. M. (2014). Winsteps Rasch measurement computer program. Beaverton: Winsteps.com.

Machado, W. L., Vissoci, J. \& Epskamp, S. (2015). Análise de rede aplicada à Psicometria e à Avaliação Psicológica [Network analysis applied to Psychometry and Psychological Assessment]. In C. S. Hutz, D. R. Bandeira \& C. M. Trentini (Orgs.). Psicometria [Psychoemetry] (pp. 125-146). Porto Alegre: Artmed.

McCann, S. C., Jowdy, D. P. \& Van Raalte, J. L. (2011). Avaliaçãoo em Psicologia do Esporte [Assessment in Sport Psychology]. In J. L. Van Raalte \& B. W. Brewer. Psicologia do Esporte [Sport Psychology] (2 ed., pp. 291-305, H.T. Bachup, Trad.). São Paulo: Santos Editora.

McGrath, P. J., Walco G. A., Turk, D. C., Dworkin, R. H., Brown, M. T., Davidson, K., ... Zeltzer, L. (2008). Consensus statement: Core outcomes domains and measures for pediatric acute and chronic/recurrent pain clinical trials. PedIMM-PACT 
recommendations. The Journal of Pain, 9(9), 771-783. https:// dx.doi.org/10.1016/j.jpain.2008.04.007

Motta, A. B. \& Enumo, S. R. F. (2010). Intervenção psicológica lúdica para o enfrentamento da hospitalização em crianças com cáncer [Recreational psychological intervention for coping with hospitalization in children with cancer]. Psicologia: Teoria e Pesquisa, 26(3), 445-454. https://dx.doi.org/10.1590/ S0102-37722010000300007

Nilsson, C., Leanderson, J., Wykman, A. \& Strender, L. E. (2001). The injury panorama in a Swedish professional ballet company. Knee Surgery, Sports Traumatology, Arthroscopy, 9(4), 242-246. https://doi.org/10.1007/001670100195

Nunnally, J. C. (1978). Psychometric theory. New York: McGraw-Hill. Oliveira, C. G.T., Enumo, S. R. F. \& Paula, K. M. P. (2017). A psychological intervention proposal on coping with pain for children with Sickle Cell Disease. Estudos de Psicologia (Campinas), 34(3), 355-366. https://dx.doi.org/10.1590/198202752017000300004

Pacico, J. C. \& Hutz, C. M. (2015). Validade [Validity]. In C. M. Hutz, D. R. Bandeira \& C. M. Trentini. Psicometria [Psychometry] (pp. 71-84). Porto Alegre: Artmed.

Pasquali, L. (2004). Psicometria: Teoria dos testes na Psicologia e na Educação [Psychometry: Tests theory in Psychology and Education]. Petrópolis: Vozes.

Patara, C. R. T. (2010). Adolescência: Aspectos clínicos [Adolescence: Clinical aspects]. In V. A. C. Tricoli (Org.), Stress na adolescência: Problemas e solução, a possibilidade de jovens estressados se tornarem adultos saudáveis [Stress in adolescence: Problems and solution, the possibility of stressed youngsters becoming healthy adults] (pp. 21-37). São Paulo: Casa do Psicólogo.

Peixoto, E. M. \& Nakano, T. C. (2014). Problemas e perspectivas na utilização dos testes psicológicos em Psicologia do Esporte [Problems and perspectives in the use of psychological tests in Sport Psychology]. In C. R. Campos \& T. C. Nakano. Avaliação 
Psicológica direcionada a populaçôes específicas [Psychological evaluation directed to specific populations] (pp. 201-232). São Paulo: Vetor Editora.

Perroni, M. G. (2007). Estudos de casos: Lesóes musculoesqueléticas em atletas de voleibol do alto rendimento [Case studies: Musculoskeletal injuries in high-performance volleyball athletes]. Master Dissertation, Universidade Federal do Rio Grande do Sul, Porto Alegre, RS, Brazil. Retrieved from: http://hdl.handle. net/10183/12898

Persike, M. \& Seiffge-Krenke, I. (2012). Competence in coping with stress in adolescents from three regions of the world. Journal of Youth and Adolescence, 41(7), 863-879. https://doi.org/10.1007/ s10964-011-9719-6

Persike, M. \& Seiffge-Krenke, I. (2015). Stress with parents and peers: How adolescents from 18 nations cope with relationship stress. Anxiety, Stress \& Coping, 29(1), 38-59. https://dx.doi.org/10.10 80/10615806.2015.1021249

Ramos, F. P., Enumo, S. R. F. \& Paula, K. M. P. (2015). Teoria Motivacional do Coping: Uma proposta desenvolvimentista para a análise do enfrentamento do estresse [Motivational Theory of Coping: A developmental proposal for the analysis of coping with stress]. Estudos de Psicologia (Campinas), 32(2), 269-279. https://dx.doi.org/10.1590/0103-166X2015000200011

Reichardt, J. \& Bomholdt, S. (2008). Statistical mechanics of community detection. Retrieved from: http://snap.stanford.edu/class/ cs224w-readings/reichardt06community.pdf

Sameroff, A. J. (2009). Conceptual issues in studying the development of self-regulation. In S. L. Olson \& A. J. Sameroff (Eds.), Biopsychosocial regulatory processes in the development of childhood behavioral problems (pp. 1-18). New York: Cambridge University Press.

Seiffge-Krenke, I. (2013). Stress, coping and relationship in adolescence. New York: Psychology Press. 
Silva, A. M. B., Luz, T. S. R., Afonso, R. M., Araújo, M. F., Bittencourt, I. G., Carvalho, L. F. \& Enumo, S. R. F. (2015). Escala de Autoeficácia para Bailarinos (AEBAI): Construçáo e evidências de validade [Self-efficacy Scale for Dancers (SESD): Construction and validity evidences]. Avaliação Psicológica, 14(1), 83-88. Retrieved from: http://pepsic.bvsalud.org/scielo.php? script=sci_arttext\&pid=S1677-04712015000100010\&lng=pt \&thng=pt

Singh, S. (2011). The meaning of pain during the process of embodiment: A case study of trainee modern dancers' experiences of pain. Sport, Education and Society, 16(4), 451-465. https:// dx.doi.org/10.1080/13573322.2011.589643

Skinner, E. A., Edge, K., Altman, J. \&Sherwood, H. (2003). Searching for the structure of coping: A review and critique of category systems for classifying ways of coping. Psychological Bulletin, 129(2), 216-269. https://doi.org/10.1037/0033-2909.129.2.216

Skinner, E. A. \& Wellborn, J. G. (1994). Coping during childhood and adolescence: A motivacional perspective. In D. L. Featherman, R. M. Lerner \& M. Perlmulter (Eds.), Life-Span Development and Behavior (v. 12, pp. 91-133). Hillsdale, NJ: Lawrence Erlbaum Associates.

Skinner, E. A., Zimmer-Gembeck, M. J. (2016). The development of coping: Stress, neurophysiology, social relationships, and resilience during childhood and adolescence. USA: Springer.

Smith, P. J., Gurie, B. J., Varner, K. E., McCulloch, P. C., Lintner, D. M. \& Harris, J. D. (2015). Incidence and prevalence of musculoskeletal injury in ballet: A systematic review. Orthopaedic Journal of Sports Medicine, 3(7), 1-9. https://dx.doi. org/10.1177/2325967115592621

Van Damme, S., Crombez, G. \& Eccleston, C. (2008). Coping with pain: A motivational perspective. Pain, 139(1), 1-4. https://doi. org/10.1016/j.pain.2008.07.022

Von Baeyer, C. L. (2013). Self-report: The primary source in assessment after infancy. In P. J. McGrath, B. J. Stevens, S. M. Walker \& W. 
T. Zempsky (Eds.), Oxford Textbook of Paediatric Pain (pp. 1-21). Oxford: Oxford University Press. https://dx.doi.org/10.1093/ $\mathrm{med} / 9780199642656.003 .0036$

Vowles, K. E., McCracken, L. M., Sowden, G. \& Ashworth, J. (2014). Psychological flexibility in coping with chronic pain: Further examination of the Brief Pain Coping Inventory-2. The Clinical Journal of Pain, 30(4), 324-330. https://doi.org/10.1097/ AJP.0b013e31829ea187

Watkins, M. W. (2006). Determining parallel analysis criteria. Journal of Modern Applied Statistical Methods, 5(2), 344-346. https:// doi.org/10.22237/jmasm/1162354020

Wright, B. D. \& Masters, G. N. (1982). Rating scale analysis. Chicago: MESA.

Yan, Z. \& Mok, M. M. C. (2012). Validating the coping scale for Chinese athletes using multidimensional Rasch analysis. Psychology of Sport and Exercise, 13(3), 271-279. https://doi.org/ 10.1016/j.psychsport.2011.11.013

Zempsky, W. T., O’Hara, E. A., Santanelli, J. P., New, T., SmithWhitley, K., Casella, J., ... Palermo, T. M. (2014). Development and validation of the Youth Acute Pain Functional Ability Questionnaire (YAPFAQ). The Journal of Pain, 15(2), 13191327. https://doi.org/10.1016/j.jpain.2014.09.008

Zimmer-Gembeck, M. J. \& Skinner, E. A. (2008). Adolescents' coping with stress: Development and diversity. Cancer Prevention Research, 15(1), 3-7.

Zimmer-Gembeck, M. J. \& Skinner, E. A. (2011). The development of coping across childhood and adolescence: An integrative review and critique of research. International Journal of Behavioral Development, 35(1), 1-17. https://dx.doi. org/10.1177/0165025410384923

Recibido: 9 de noviembre, 2017

Revisado: 26 de junio, 2018 Aceptado: 30 de agosto, 2018 


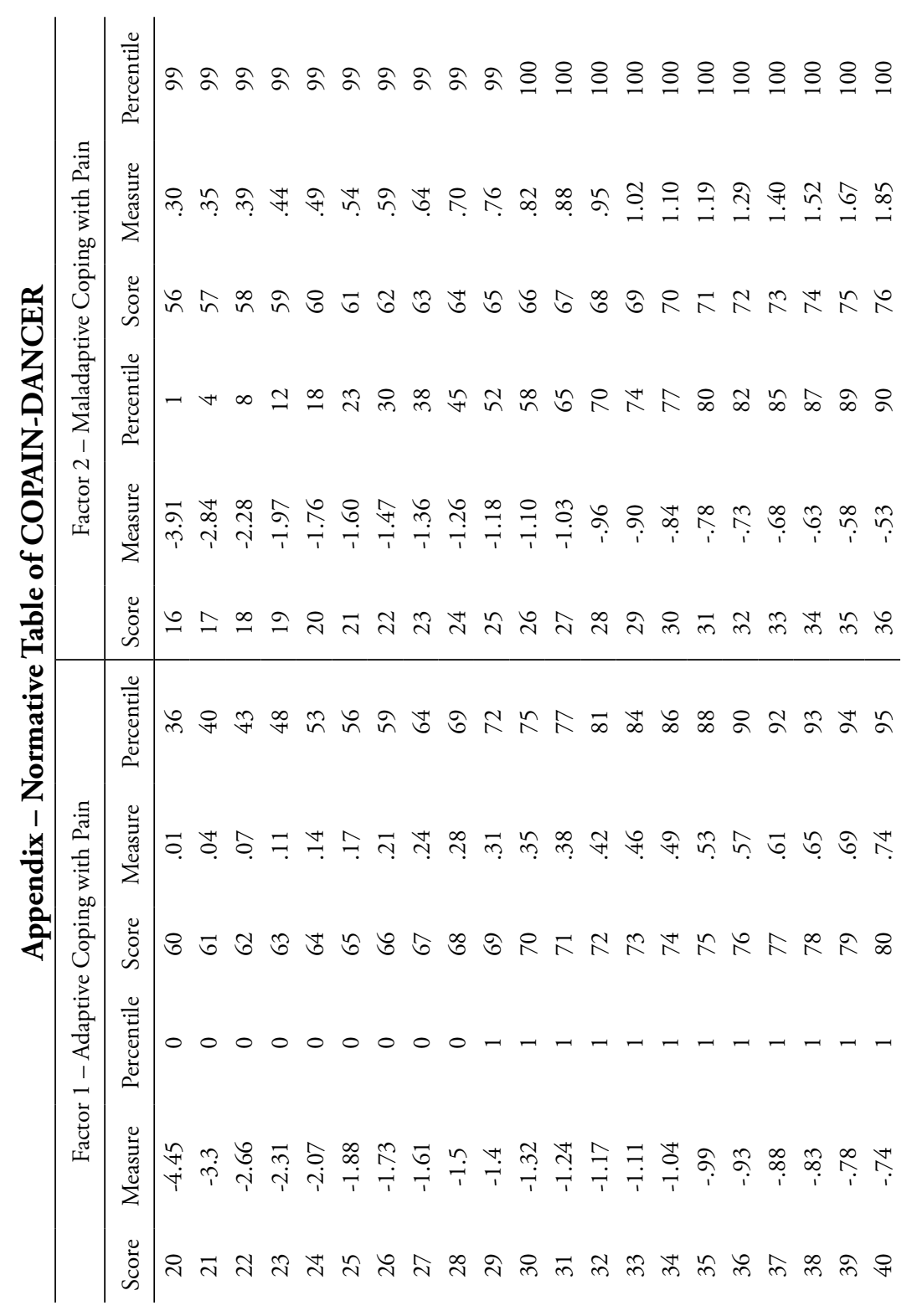


Scale of Coping with Pain for Dancers (COPAIN-Dancer) / Da Silva et al.

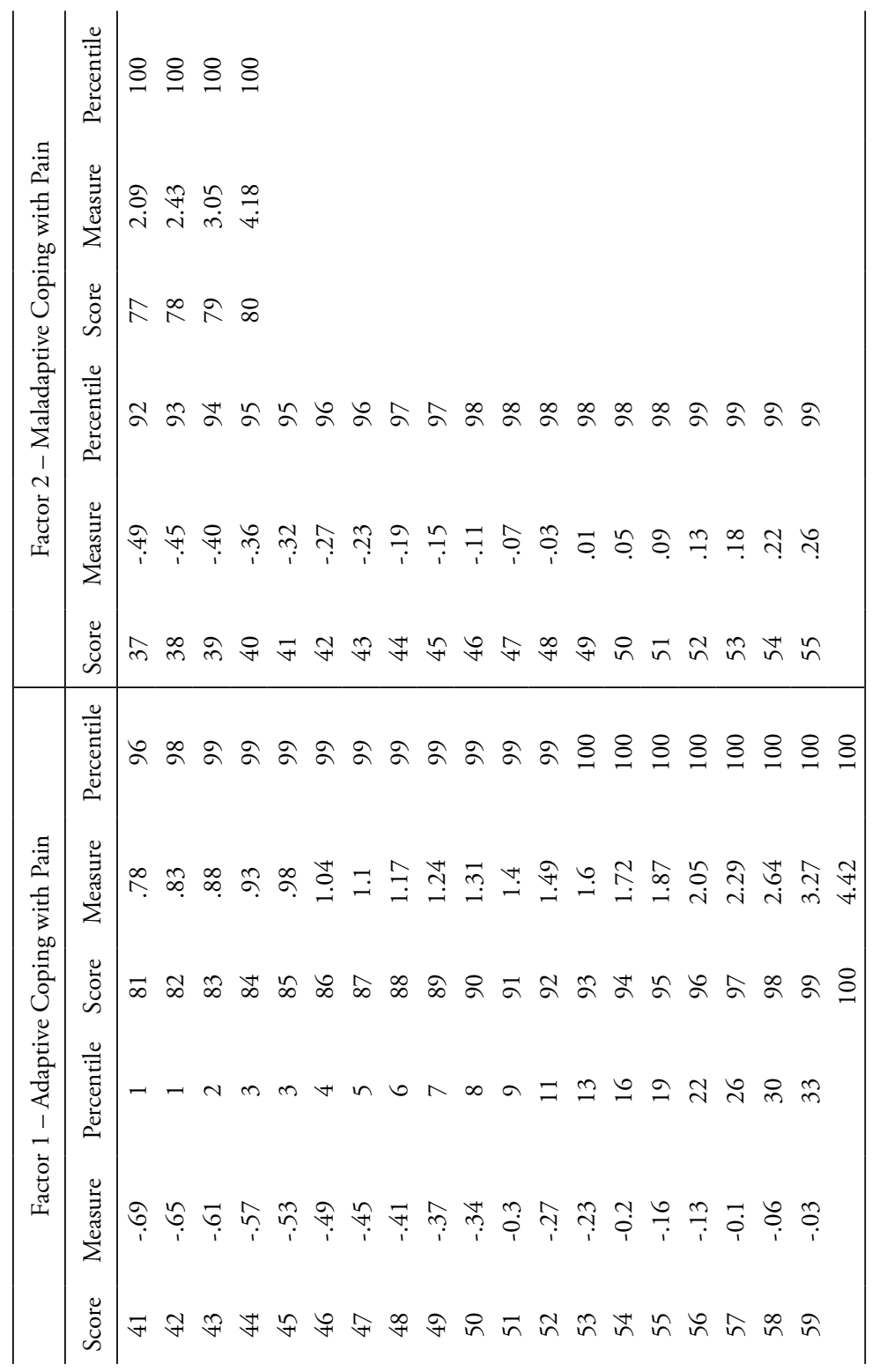

